Additional Perspectives articles for Influenza: The Cutting Edge book collection are available at http://perspectivesinmedicine.cshlp.org/cgi/collection/influenza_the_cutting_edge.

\title{
The Two Sides of the Same Coin-Influenza Virus and Intracellular Signal Transduction
}

\author{
Stephan Ludwig, Eike R. Hrincius, and Yvonne Boergeling \\ Institute of Virology Muenster, University of Muenster, 48149 Muenster, Germany \\ Correspondence: ludwigs@uni-muenster.de
}

Cells respond to extracellular agents by activation of intracellular signaling pathways. Viruses can be regarded as such agents, leading to a firework of signaling inside the cell, primarily induced by pathogen-associated molecular patterns (PAMPs) that provoke safeguard mechanisms to defend from the invader. In the constant arms race between pathogen and cellular defense, viruses not only have evolved mechanisms to suppress or misuse supposedly antiviral signaling processes for their own benefit but also actively induce signaling to promote replication. This creates viral dependencies that may be exploited for novel strategies of antiviral intervention. Here, we will summarize the current knowledge of activation and function of influenza virus-induced signaling pathways with a focus on nuclear factor (NF)- $\kappa \mathrm{B}$ signaling, mitogen-activated protein kinase cascades, and the phosphatidylinositol-3-kinase pathway. We will discuss the opportunities and drawbacks of targeting these signaling pathways for antiviral intervention.

\begin{abstract}
Communication among cells is commonly achieved by released extracellular factors that act on neighboring or distant cells. Through the binding of these factors (e.g., growth factors or cytokines) to surface receptors of target cells, intracellular signaling pathways mostly governed by GTPases and kinases are activated to transform the extracellular signal into a cellular response. Viruses also activate a variety of intracellular signaling pathways and may be seen as a special kind of stimulus, because their signaling-promoting activity changes dynamically throughout the replication cycle. The picture has emerged that most of these signaling pathways are activated by the cell to fight the invading pathogen. However, viruses also appear to exploit or even specifically activate intracellular signaling processes to drive their replication cycle.
\end{abstract}

A hallmark cellular response induced by RNA virus infection, including influenza viruses (IVs), is the type I interferon (IFN) response, representing a first line of defense against viral invaders. For a long time, it was enigmatic how the cell senses an infection and how this is converted into type I IFN expression. It was only in the early 2000s that the cytoplasmic helicase retinoic acid inducible gene I (RIG-I) was identified as a receptor for viral RNA (for review, see Takeuchi and Akira 2008), later followed by the finding that the $5^{\prime}$-triphosphate end $\left(5^{\prime} \mathrm{PPP}\right)$ of viral RNA is the major pathogen-associated molecular pattern (PAMP) that provokes RIGI activation (Hornung et al. 2006). Since then, a complete signaling pathway has been dissected, including recruitment of RIG-I to the signaling integrator MAVS/IPS-1 at the mitochondria,

Editors: Gabriele Neumann and Yoshihiro Kawaoka

Additional Perspectives on Influenza: The Cutting Edge available at www.perspectivesinmedicine.org

Copyright (C) 2021 Cold Spring Harbor Laboratory Press; all rights reserved; doi: 10.1101/cshperspect.a038513

Cite this article as Cold Spring Harb Perspect Med 2021;11:a038513 
S. Ludwig et al.

leading to downstream activation of TBK-1/ $\mathrm{IKK} \varepsilon$, which phosphorylates and activates the major IFN-inducing transcription factor, IFN regulatory factor 3 (IRF3) that acts in concert with nuclear factor (NF)- $\mathrm{\kappa B}$ and activating transcription factor 2 (ATF-2)/c-Jun to drive the
IFN- $\beta$ enhanceosome (Fig. 1) (for reviews, see Pichlmair et al. 2006; Killip et al. 2015). The utmost importance of this signaling chain for the innate antiviral response is probably best highlighted by the fact that many, if not all, viruses have evolved gene products to suppress or
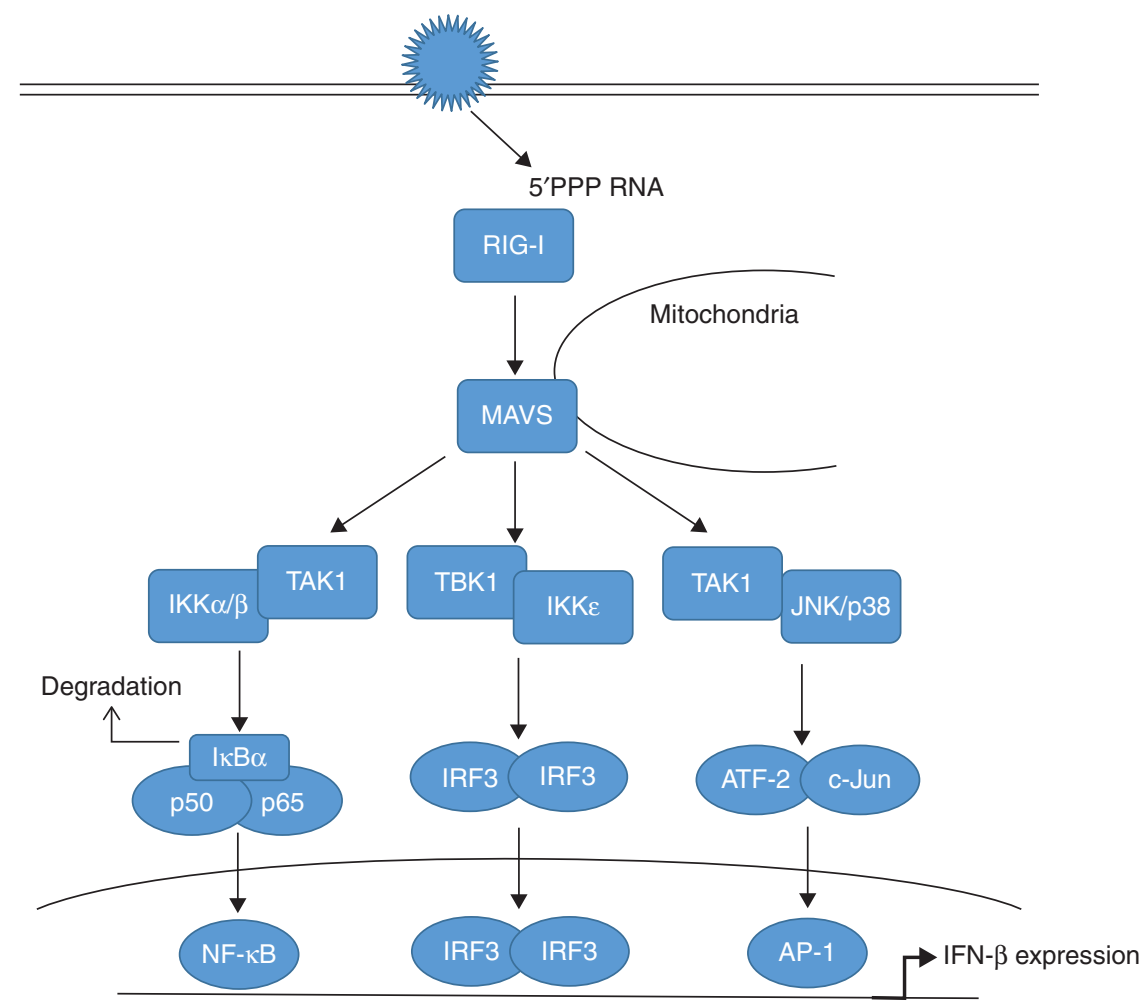

IFN- $\beta$ enhanceosome

Figure 1. Retinoic acid inducible gene (RIG)-I-dependent type I interferon induction. During infection of host cells with influenza viruses (IVs), incoming or newly synthesized $5^{\prime}$-triphosphorylated viral RNA ( $5^{\prime} \mathrm{PPP}$ RNA) is sensed as a pathogen-associated molecular pattern (PAMP) by the ubiquitously expressed cytoplasmic sensor RIG-I. RIG-I triggers via the adapter MAVS (mitochondrial antiviral signaling) signal transduction cascades that result in the activation of different transcription factors. The major MAVS signaling complex consist of tumor necrosis factor (TNF) receptor-associated factor (TRAF) 3 and TANK-binding kinase 1 (TBK1) inducing inhibitor of IkB-kinase- $\varepsilon$ (IKKع) activity. This results in the phosphorylation of the constitutively expressed interferon (IFN) regulatory factor 3 (IRF3) as well as the induced factor IRF7, belonging to the set of IFNstimulated genes (ISGs) induced during infection. IRF3 and IRF7 homodimers as well as IRF3/7 heterodimers translocate into the nucleus to induce synthesis of type I IFN mRNAs via binding to the IFN- $\beta$ enhanceosome. A second signaling complex consisting of TRAF6 and TGF- $\beta$-activated kinase 1 (TAK1) induces the activation of IKK $\beta$. IKK $\beta$ phosphorylates the inhibitor of $\mathrm{KB}(\mathrm{I} \kappa \mathrm{B} \alpha)$, a protein masking the nuclear localization signals (NLSs) of nuclear factor (NF) $-\kappa B$ transcription factors, keeping them sequestered in an inactive state in the cytoplasm. This phosphorylation results in the dissociation of $\mathrm{I} \kappa \mathrm{B} \alpha$ from NF- $\kappa \mathrm{B}$, which migrates into the nucleus. Additionally, TAK1 activates mitogen-activated protein kinases (MAPKs) p38 and JNK (c-Jun amino-terminal kinase) resulting in the phosphorylation of activating transcription factor 2 (ATF-2) and c-Jun, which dimerize and translocate to the nucleus. Activity of these transcription factors collectively mediates full activation of the IFN- $\beta$ promoter. 
prevent its activation. For IV, the main interferon antagonistic protein is the viral nonstructural protein 1 (NS1) that interferes with the interferon-inducing cascade at several levels (for reviews, see Hale et al. 2008a; Krug 2015). However, other IV proteins have also been identified to suppress the RIG-I pathway, mainly encoded by the polymerase genes, such as PB1/PA (Liedmann et al. 2014), PB2 (Graef et al. 2010), or PB1-F2 (Dudek et al. 2011; Varga et al. 2011), which interestingly all seem to interfere with the adapter protein MAVS.

Although the RIG-I/MAVS/IRF3/IFN- $\beta$ signaling axis as well as its regulators and modifiers have been reviewed extensively elsewhere as a hallmark prototype pathway for antiviral signaling (Killip et al. 2015; Krug 2015; Weber-Gerlach and Weber 2016; García-Sastre 2017), there are still many other signaling events induced by IVs, some of which even showing virus-supportive functions. Here, we will summarize recent findings on these signaling cascades beyond the RIG-I/IRF3 pathway, with a major emphasis on $\mathrm{NF}-\mathrm{kB}$ signaling, mitogen-activated protein kinase cascades and the phosphatidylinositol-3kinase pathway.

\section{NUCLEAR FACTOR $\kappa B$}

The transcription factor NF- $\mathrm{KB}$ is activated by many pathogens including IV, and plays an important role in type I IFN induction, acting in concert with IRF3 and AP- 1 at the IFN- $\beta$ enhanceosome (Fig. 1). However, it turned out that the factor fulfills additional functions during IV infections.

The NF- $\kappa \mathrm{B}$ family of transcription factors comprises seven distinct members with transcription regulatory properties (for review, see Napetschnig and Wu 2013). NF- $\mathrm{KB}$ is a central factor in the regulation of cellular processes such as inflammatory responses to pathogens or controlled cell death mechanisms (apoptosis) (for review, see Lawrence 2009). In addition, NF- $\kappa B$ has been shown to be activated by infection with a wide range of viral pathogens (for review, see Santoro et al. 2003). Historically, NF- $\mathrm{kB}$ was considered as a central antiviral-acting signaling module because it coregulates the activation of
Influenza Virus and Cellular Signal Transduction

the IFN system in addition to its general immune stimulatory capacities (for review, see Pahl 1999). In line with these findings, NF-kB signaling was identified to be mainly responsible for the hyperactivation of inflammatory and antiviral responses upon infection with $\mathrm{H} 5 \mathrm{~N} 1$ highly pathogenic avian IV (Schmolke et al. 2009; Viemann et al. 2011). Contrarily, infection with low pathogenic IV seems to induce a negative feedback loop resulting in NF-kB-dependent diminishment of IFN-induced antiviral responses (Wei et al. 2006; Pauli et al. 2008).

Further challenging the idea of an overall antiviral action of NF- $\mathrm{KB}$ in IV infection, two independent studies indicated that NF- $\kappa \mathrm{B}$ preactivation is beneficial for virus replication (Nimmerjahn et al. 2004; Wurzer et al. 2004). These data for the first time unraveled that NF$\mathrm{kB}$ activation in IV-infected cells show virussupportive functions, which was later confirmed in other studies (Kumar et al. 2008). Mechanistically, these virus-supportive functions were initially linked to NF- $\mathrm{KB}$-driven expression of the pro-apoptotic factors tumor necrosis factor (TNF)-related apoptosis-inducingligand (TRAIL) and Fas ligand (FasL), whose inactivation resulted in decreased virus titers, whereas short-term stimulation of cells with these molecules fostered virus propagation (Wurzer et al. 2004). On the molecular level, TRAIL and FasL show their proapoptotic functions by activation of caspases (for review, see Kumar et al. 2005), a group of cellular factors whose function is essential for efficient growth of IV (Wurzer et al. 2003). Caspase activity results in proteolytic cleavage of diverse target molecules during apoptotic processes, but also carries immune stimulatory capacities by cleavage of factors such as pro-interleukin- $1 \beta$ into its active form (for review, see Lopez-Castejon and Brough 2011). In IV-infected cells, inhibition of caspases resulted in the retention of newly synthesized viral ribonucleoprotein (vRNP) complexes in the nucleus (Wurzer et al. 2003). This process was explained by caspase-mediated widening of nuclear pore complexes caused by the proteolytic cleavage of nuclear pore forming proteins, thus representing a beneficial step in virus replication (Kramer et al. 2008; Mühlbauer et al. 2015). Therefore, 
S. Ludwig et al.

in addition to active chromosomal maintenance 1 (CRM1)-mediated export of newly synthesized vRNPs ( for review, see Eisfeld et al. 2015), a caspase-mediated widening of nuclear pores is conceivable as strengthening mechanism for viral replication by allowing passive diffusion of vRNPs out of the nucleus at later stages of infection.

Based on the finding that NF- $\kappa \mathrm{B}$ shows virus-supportive functions via control of caspase activity in IV-infected cells, first ideas of targeting NF- $\kappa \mathrm{B}$ as a potential novel antiviral strategy arose. Using the NF- $\mathrm{BB}$ inhibiting agent acetylsalicylic acid (ASA), it has been shown that ASA treatment of cells resulted in retention of newly synthesized vRNPs in the nucleus, leading to impaired virus replication in vitro and in vivo (Mazur et al. 2007). In line with this finding, ASA treatment resulted in reduced TRAIL and FasL expression and, consequently, decreased caspase activation (Mazur et al. 2007). Further strengthening the feasibility of this strategy, ASA treatment did not result in the generation of resistant virus variants (Mazur et al. 2007) and, in addition, another NF- $\mathrm{KB}$ inhibitor, SC75741, showed IV-inhibitory action in vitro and in vivo (Ehrhardt et al. 2013; Haasbach et al. 2013a). Following the promising approach to use the well-known substance ASA as an antiviral drug, the inhalable nonacid, water-soluble salt of ASA, D,L-lysine-acetylsalicylate-glycine (LASAG), showed antiviral action in vitro and in a mouse model of IV infection (Droebner et al. 2017). These promising results prompted a first phase II clinical trial with LASAG administered as an aerosol in IV-infected hospitalized patients with symptoms of severe influenza (EudraCT 2012-004072-19). This trial verified that LASAG treatment improved the time of alleviation of influenza symptoms compared with standard of care (Scheuch et al. 2018), emphasizing the high potential of using cellular signaling molecules as targets for antiviral interventions instead of directly targeting viral structures with a high risk of inducing resistant variants.

Although these clinical developments are promising, there are still open questions, mainly with regard to the mechanism of action-that is, the balance between virus-supportive NF- $\mathrm{BB}$ functions in the course of the virus life cycle and its antiviral activities by inducing robust inflammatory and antiviral responses. A recent study using genetic mouse knockouts of NF- $\kappa \mathrm{B}$ transcription factors led to some controversial data about the consequences of complete versus partial inhibition of NF- $\kappa \mathrm{B}$ functions for IV replication (Dam et al. 2016). In addition, this study emphasized the importance of the viral genotype for susceptibility to the antiviral functions of NF- $\kappa B$. In the future, it will be important to gain further knowledge about the molecular basis of the observed phenotypes to understand the basal levels of NF- $\kappa \mathrm{B}$ activation needed to maintain critical NF- $\kappa$ B functions in the regulation of inflammatory responses.

\section{MITOGEN-ACTIVATED PROTEIN KINASES}

The family of so-called mitogen-activated protein kinase (MAPK) cascades plays important roles in the transmission of extracellular signals to regulatory proteins and thereby transmits a variety of extracellular signals into specific biological responses. These signaling modules are grouped into one family because they are all composed of a cascade of three subsequently activated kinases (MAP3K $\rightarrow$ MAP2K $\rightarrow$ MAPK) resulting in the activation of the actual MAPK (Fig. 2), which is a serine/threonine (S/T) kinase (for review, see Cargnello and Roux 2011). Conventional MAPKs include the extracellular signal-regulated kinases 1/2 (ERK1/2), c-Jun amino (N)-terminal kinases $1 / 2 / 3(\mathrm{JNK} 1 / 2 / 3)$, the p38 MAPK isoforms $(\alpha, \beta, \gamma, \delta)$, and ERK5 (for reviews, see Pearson et al. 2001; Nishimoto and Nishida 2006). All these MAPKs are activated by dual specificity kinases, called MKK or MEK, that phosphorylate the actual MAPK on threonine (T) and tyrosine (Y) in a specific TXY motif, thereby achieving high substrate specificity and signaling stringency.

\section{THE CLASSICAL MAP KINASE CASCADE (Raf/MEK/ERK)}

The Raf/MEK/ERK signaling cascade is also known as the classical MAPK cascade. Under physiological conditions, the pathway regulates 


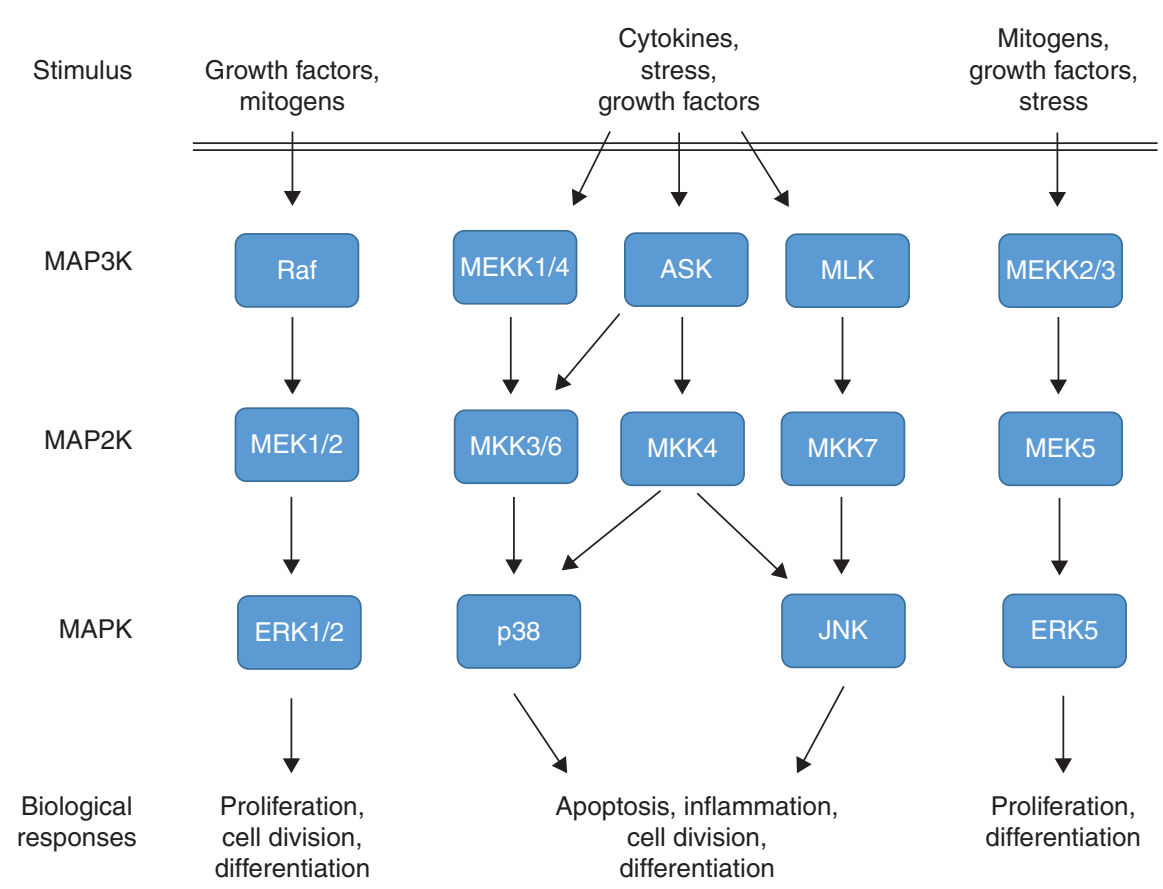

Figure 2. Mitogen-activated protein kinase (MAPK) signaling cascades. MAPK signaling cascades are organized hierarchically into three-tiered modules. MAPKs are phosphorylated and activated by MAPK kinases (MAP2K), which in turn are phosphorylated and activated by MAP2K kinases (MAP3K). MAP3Ks are activated by several modes, including interaction with the family of small GTPases and/or other protein kinases, connecting the MAPK module to cell surface receptors or external stimuli. MAPK cascades activation results in a diverse set of biological responses depending on stimulus and cellular context.

cellular processes like proliferation, differentiation, and apoptosis, depending on the cell type and activation context (for review, see Cargnello and Roux 2011). Aberrant overactivation of the pathway is often associated with tumor development; thus, many attempts have been and are still undertaken to pharmacologically inhibit the pathway on the level of MEK (for review, see Zhao and Adjei 2014). First compounds have successfully passed clinical trials and some are now licensed for clinical use (for review, see Cheng and Tian 2017), such as trametinib, which is licensed for melanoma treatment. Despite the prominent role of the Raf/MEK/ ERK cascade in cell growth and differentiation, the compounds showed surprisingly few side effects in the first weeks of treatment and were generally well-tolerated in humans.

The Raf/MEK/ERK cascade was also shown to be activated by IV infection (Pleschka et al. 2001), which can be regarded as aberrant, be- cause in resting lung epithelial cells, the pathway is usually silent. With regard to its activation, the kinase cascade is somewhat special among other IV-induced signaling cascades as it is not primarily activated by $5^{\prime} \mathrm{PPP}$ RNA. Rather, activation occurs via accumulation of viral hemagglutinin (HA) molecules in the plasma membrane (Marjuki et al. 2006). This appears to induce the formation of lipid rafts, which serve as signaling platforms for protein kinase C (PKC)-dependent Raf/MEK/ERK activation, presumably by bringing monomeric receptor molecules in close proximity to each other. Further findings showed that HA triggers a switch from MEK1 SUMOylation to activation of the ERK pathway, thereby enhancing the activity of the cascade (Wang et al. 2017).

Strikingly, it turned out that inhibition of the pathway by inhibitors of MEK or dominant negative mutants of MEK and ERK leads to reduced progeny titers of influenza $A$ and $B$ viruses 
S. Ludwig et al.

(Pleschka et al. 2001; Ludwig et al. 2004). The Raf/MEK/ERK cascade was thus considered to be the first example of a signaling pathway activated by IV for its own benefit (for review, see Yewdell and García-Sastre 2002). In search of the underlying mechanism, it was shown that inhibition of the kinase cascade did not affect viral RNA and protein synthesis, but resulted in an efficient retention of vRNPs in the nucleus of infected cells (Pleschka et al. 2001). More recent data suggest that this is not caused by a general block of CRM1-mediated export, but seems to be regulated by a posttranslational modification of the viral nucleoprotein.

Ever since the virus-supportive function of the Raf/MEK/ERK signaling cascade was unraveled, this pathway has been targeted for antiviral intervention (for reviews, see Ludwig 2009; Planz 2013). The strategy has quite some attractiveness, because, as mentioned above, several inhibitors of the central kinase MEK, representing the bottleneck of the signaling pathway, have been developed or are licensed for clinical use in cancer therapy (for reviews, see Zhao and Adjei 2014; Cheng and Tian 2017). This would allow a repurposing approach. In line with that idea, it has been shown that several MEK inhibitors, such as U0126, CI-1040 (Pleschka et al. 2001; Droebner et al. 2011; Haasbach et al. 2017), or the licensed drug trametinib (Schräder et al. 2018), display efficient anti-influenza activity not only in vitro but in the mouse model without major signs of toxicity. MEK inhibitors display a high barrier toward emergence of resistance (Ludwig et al. 2004), act synergistically with licensed drugs such as oseltamivir (Haasbach et al. 2013b), and confer a prolonged treatment window compared with standard of care in vivo (Haasbach et al. 2017).

Besides its anti-IV activity, MEK inhibitors appear to act in a much broader manner and have been shown at least in vitro to inhibit replication of other viruses (e.g., bornavirus [Planz et al. 2001] or respiratory syncytial virus [RSV] [Preugschas et al. 2019]), which is in line with the finding that several RNA viruses manipulate the Raf/MEK/ERK pathway (for review, see Pleschka 2008). Interestingly, even an antibacterial activity was shown for a specific metabo- lite of the MEK inhibitor CI-1040 (Bruchhagen et al. 2018), which is most likely conferred by a direct inhibition of a bacterial kinase.

The use of MEK inhibitors as anti-infective agents has even entered the phase of clinical development and was brought forward into phase I clinical trials (EudraCT 2019-00078425), showing safety of the product in healthy human individuals.

Despite the accumulated knowledge about Raf/MEK/ERK involvement in IV replication, there are still open questions to address. The detailed molecular mechanism by which the pathway controls vRNP export is still elusive and it is not entirely clear whether an additional involvement of the kinase cascade in the regulation of innate cytokine responses may contribute to the antiviral activity of MEK inhibitors in vivo (Pinto et al. 2011; Schräder et al. 2018) or rather acts virus-supportive by inhibiting downstreamacting p90 ribosomal S6 kinase 2 (RSK2) and its functions in the establishment of antiviral responses (Kakugawa et al. 2009). Still, other factors required for virus replication may be controlled by the pathway-for example, the vacuolar ATPase that stimulates endosomal acidification required for viral fusion (Marjuki et al. 2011).

\section{STRESS-INDUCED MAPKs JNK AND p38}

MAPKs JNK and p38 were identified in the early 1990s and are now recognized as kinases preferentially responsive to stress stimuli compared with the classical MAPK ERK (Kyriakis and Avruch 1990; Hibi et al. 1993; Han et al. 1994; Lee et al. 1994; Rouse et al. 1994). Meanwhile, it is well documented that the JNK and p38 MAPK pathways are activated by various external stimuli, including pro-inflammatory cytokines and virus infections (for reviews, see Bogoyevitch et al. 2010; Cuadrado and Nebreda 2010). After activation, JNK and p38 have been shown to regulate a large number of substrates including protein kinases coordinately regulating many different cellular functions such as inflammatory responses, apoptosis, proliferation, and differentiation (for reviews, see Cargnello and Roux 2011; Morrison 2012). 
The first report on the activation of these kinases in IV replication was provided by $\mathrm{Ku}$ jime and colleagues in 2000 (Kujime et al. 2000). During IV infection, different stimuli seem to concomitantly orchestrate the activation of stress-induced MAPK pathways. Particularly, the common IV PAMP 5'PPP RNA that accumulates during IV replication has been shown to activate MAPKs JNK and p38 via the RIG-I receptor signaling pathway (Ludwig et al. 2001; Nacken et al. 2014; Jiang et al. 2015). Being an antagonist of this pathway, the viral NS1 protein has been identified to suppress virus-induced activation of JNK (Ludwig et al. 2002). However, it seems that JNK can also be activated by NS1 variants encoding phenylalanine at amino acid position 103 (Nacken et al. 2014). So far, the mechanism of this RIG-I independent NS1-mediated JNK activation and the extent to which it is crucial for the control of replication remain elusive.

Concerning MAPK p38, Pan and colleagues unraveled an involvement of viral HA-induced autophagy in p38 activation by using replication-incompetent $\mathrm{H} 5 \mathrm{~N} 1$ pseudotyped viral particles (Pan et al. 2014). Furthermore, there are implications of IV infection-induced reactive oxygen species (ROS) that trigger MAPK p38 pathway activation (Amatore et al. 2015). Intriguingly, dependent on the mechanistic context of JNK and p38 activation during IV replication, these kinases seem to induce different responses.

In the past, activation of JNK and p38 MAP kinase cascades has been shown to play a major role in the modulation of IV-induced cell intrinsic immune responses (Kujime et al. 2000; Hayashi et al. 2008). MAPK JNK, but not p38, was hypothesized to be responsible for IV-induced activation of transcription factor AP-1 by phosphorylating ATF-2 (Ludwig et al. 2001). However, p38 seems to act on two levels of the IV-induced antiviral IFN response. Initially, the kinase regulates IFN induction, but also controls IFN signaling and thereby expression of IFN-stimulated genes by coregulating transcription factor signal transducer and activator of transcription 1 (STAT1) via phosphorylation of its transactivation domain at serine 727
Influenza Virus and Cellular Signal Transduction

(Börgeling et al. 2014). Moreover, it has been shown that MAPK p38 also controls the expression of type III IFN in response to IV RNA stimulation (Jiang et al. 2015). At the same time, MAPK p38 catalyzes a negative feedback phosphorylation of MK3 that causes decreased binding of STAT 4 to the IFN- $\gamma$ promoter, resulting in reduced IFN- $\gamma$ expression upon IV infection (Köther et al. 2014). Surprisingly, despite its undoubtedly important function in the modulation of IFN responses induced by IV infection, there is considerably less information available concerning the discrete involvement of MAPK JNK during IFN-mediated antiviral responses (for review, see Stanifer et al. 2019).

Because of its prominent role in cytokine expression in IV infection (Hui et al. 2009), inhibition of p38 has been shown to protect mice from lethal IV infections as a result of decreased cytokine-induced immunopathology (Börgeling et al. 2014; Wei et al. 2014; Growcott et al. 2018). Recently, a new mechanism by which MAPK p38 affects dysregulation of cytokine induction was unraveled, deciphering an IV strain-specific phosphorylation of transcriptional repressor TRIM28 (tripartite motif-containing 28) at S473, which is induced by a signaling cascade constituted of protein kinase $\mathrm{R}$ (PKR), p38 MAPK and MSK1 in response to RIG-I-independent sensing of viral 5'PPP RNA. By using chemical inhibitors as well as knockout cell lines, it was shown that MAPK p38-dependent phosphorylation of TRIM28 facilitates a functional switch leading to increased cytokine levels in cells infected with highly pathogenic viruses (Krischuns et al. 2018). Besides its role in the induction of pro-inflammatory and antiviral cytokines, there have been reports of a virus-supportive function of MAPK p38 observed after inhibition of the pathway with different p38 inhibitors (Marchant et al. 2010; Choi et al. 2016; McCaskill et al. 2017). Deeper investigation provided evidence of a potential role of p38 in Toll-like receptor 4-mediated virus internalization, which is based on p38catalyzed phosphorylation of early endosome antigen 1 (EEA1), which increases endocytotic activity. Therefore, upon IV infection, inhibition of p38 leads to a retention of viral particles 
S. Ludwig et al.

in EEA1-positive endosomes (Macé et al. 2005; Marchant et al. 2010). In addition, Nencioni and colleagues (2009) described a retention of viral RNPs in the nucleus of IV-infected cells after inhibition of MAPK p38. These investigators hypothesized a direct phosphorylation of the viral nucleoprotein as well as a p38-catalyzed inactivation of the anti-apoptotic acting protein B-cell lymphoma 2 (Bcl-2) that enables IV-induced apoptosis progression and, therefore, efficient release of vRNPs from the nucleus. Interestingly, a major proportion of MAPK p38 antiviral activity was pinpointed to its downstream target MK2 (McCaskill et al. 2017). It was shown previously that IV-induced $\mathrm{MK} 2 / 3$ activation is mainly dependent on p38 activity (Luig et al. 2010). Active MK2/3 interacts with p88, the repressor of PKR inhibitor p58 (rIPK), thereby forming a trimeric complex including antiviral acting PKR that cannot longer be activated by binding to dsRNA. Thus, PKR-induced inactivation of eIF $2 \alpha$ (eukaryotic initiation factor 2) is inhibited, allowing for efficient capdependent translation of cellular and viral proteins (Luig et al. 2010).

Strikingly, the MAPK JNK pathway also seems to play a bivalent role in IV infection. Blockade of the pathway by small-molecule inhibitors competing with ATP-binding of JNK was shown to decrease viral replication in vivo and in vitro by suppressing viral protein and RNA synthesis that might be mediated by inhibition of NS1-induced increases in viral polymerase activity (Nacken et al. 2012; Zhang et al. 2016). Nevertheless, the underlying mechanisms behind these observations remain obscure. In past studies, IV infection-induced JNK activity was mainly linked to apoptosis induction (Lin et al. 2001; Hrincius et al. 2010), either by promoting pro-apoptotic gene expression or by interference with anti-apoptotic proteins located in mitochondria (for review, see Brydon et al. 2005). Although apoptosis induction late in the virus life cycle was shown to be beneficial for efficient viral replication (Mühlbauer et al. 2015), interference with JNK-mediated apoptosis induction via overexpression of dominant negative forms of different cascade members (Ludwig et al. 2001, 2002) or by knockdown of JNK-regulating adapter protein CRK (Hrincius et al. 2010) clearly pointed toward an antiviral property of this JNK-mediated response. However, functional consequences of NS1-induced JNK activation still remain elusive and were shown to be independent of apoptosis induction in genuine infection (Nacken et al. 2017). A more recent report points toward an involvement of MAPK JNK in the induction of IV-mediated autophagy (Zhang et al. 2019), which was suggested to lead to reduced antiviral responses (Perot et al. 2018) and, thus, increased viral replication. Nevertheless, this activity is still controversially discussed because MAPK JNKmediated autophagy induction was shown to also lead to the sequestration of vRNP complexes into autophagosomes (Kuroki et al. 2018).

Inhibition of different functions of stressinduced MAP kinases on IV infection seems to lead to diverse effects in IV amplification, suggesting that the p38 and JNK signaling cascades belong to dual mode of action pathways with respect to virus propagation. Although direct inhibition of MAPK p38 by small molecule inhibitors resulted in protection from lethal IV infections by limiting immunopathology in vivo, effects of JNK inhibition are less concrete. Further research will be needed to define the distinct virus-supportive functions of JNK-mediated responses as well as the specific cascade composition to identify the most promising target for antiviral interventions without limiting antiviral functions of the MAPK JNK pathway.

\section{PHOSPHATIDYLINOSITOL-3-KINASE}

The family of phosphatidylinositol-3-kinase (PI3K) molecules consists of different classes (class IA, IB, II, and III) (for review, see Vanhaesebroeck et al. 2016). The class IA type, which is most investigated in the context of IV infections, in general is composed of one out of three p110 catalytic subunits and one out of five p85 regulatory subunits (for review, see Thorpe et al. 2015). In physiological settings, signaling is initiated by activation of PI3 kinase activity through, for example, activated plasma membrane receptors, resulting in generation of phosphatidylinositol-3,4,5-triphosphate (PIP3) from 
phosphatidylinositol-4,5-bisphosphate (PIP2) in the plasma membrane (Fig. 3). Subsequently, PIP3 phospholipids act as second messengers for initiation of a diverse downstream signaling network (for review, see Vanhaesebroeck et al. 1997). Through this sophisticated mode of action by a PI3K-produced second messenger signaling platform, PI3K signaling modules have the capacity to regulate diverse cellular processes, ranging from proliferation to apoptosis (for review, see Katso et al. 2001).

Upon IV infection, PI3K is one of the cellular factors directly activated by the virus through defined molecular interactions. PI3K is the only known signaling factor that is directly activated by IV NS1, rather than being indirectly suppressed by the protein (Ehrhardt et al. 2006; Hale et al. 2006; Shin et al. 2007a). First implications for PI3K functions in virus replication were obtained by the finding of a dynamic, virus life cycle-dependent PI3K activation (Ehrhardt et al. 2006; Hale et al. 2006). An early, transient activation after virus addition is triggered by virus attachment and entry processes (Ehrhardt et al. 2006; Eierhoff et al. 2010), whereas a later, more robust activation was attributed to the NS1-mediated direct induction of the PI3K signaling module (Ehrhardt et al. 2006, 2007a, Hale et al. 2006, Shin et al. 2007a,b). This NS1 function was shown to be specific for NS1 of IAV as IBV NS1 failed to induce PI3K activity (Ehrhardt et al. 2007b). Another study indicated that an overexpressed H5N1 NS1 was not able to activate PI3K signaling in contrast to $\mathrm{H} 1 \mathrm{~N} 1$, $\mathrm{H} 3 \mathrm{~N} 2$, and H9N2 NS1 proteins tested in parallel. This argues for an IV strain-dependent activation of PI3K ( $\mathrm{Li}$ et al. 2012). Further strengthening this idea, it was shown that bat IV NS1 proteins do not induce PI3K activity (Turkington et al. 2018).

Regarding the mechanism of NS1-mediated PI3K activation, it has been shown that NS1 binds to the regulatory subunit p85 of PI3K via specific protein-protein interaction motifs in both interaction partners. NS1 carries Src homology (SH) binding motifs (SHbms), which

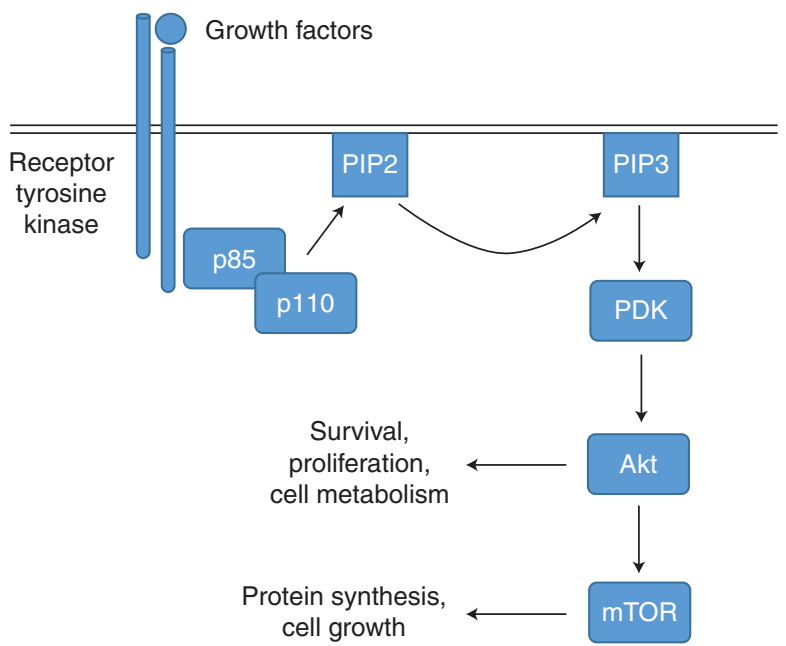

Figure 3. The phosphatidylinositol-3-kinase (PI3) pathway. PI3K is activated by binding of the regulatory subunit p85 to activated tyrosine kinase receptors or G-protein-coupled receptors. The catalytic subunit p110 generates phosphatidylinositol-3,4,5-triphosphate (PIP3) by phosphorylation of phosphatidylinositol-4,5-bisphosphate (PIP2) in the membrane, which in turn functions as a second messenger through interaction with pleckstrin homology domain-containing proteins such as phosphoinositide-dependent kinase (PDK). Activation of PDK results in the dual phosphorylation of protein kinase B (PKB/Akt). Akt phosphorylates multiple substrates resulting in the regulation of several processes such as cell survival, proliferation, or cell metabolism. Through the modification of mechanistic target of rapamycin (mTOR) signaling, PI3K further modulates cellular functions such as protein synthesis and cell growth. 
S. Ludwig et al.

can bind to SH domains in the p85 subunit of PI3K. The NS1 and PI3K p85 interactome has been extensively studied and multiple interactions seem to be involved in NS1-mediated PI3K activation (for review, see Ehrhardt and Ludwig 2009). This includes the SH2-binding motif around amino acids 89-93 (Hale et al. 2006) and the first SH3bm spanning amino acids 164-167 of NS1 (Shin et al. 2007b). Functional consequences have been shown for the disruption of both SHbms of NS1. Infection with mutant viruses lacking PI3K-activating abilities results in smaller plaque phenotypes and decreased virus titers (Hale et al. 2006, Shin et al. 2007b). Additional investigation of the molecular basis for NS1-mediated PI3K activation provided further insights into the complex, multilayered interaction network of NS1 and PI3K and the potential mode of NS1-driven PI3K activation (Hale et al. 2008b, 2010).

In addition to PI3K activation during the virus entry processes and a direct pathway induction via the NS1 protein, viral 5'PPP RNA in infected cells triggers PI3K activation, suggesting that the kinase can be alternatively activated via the common RIG-I pathway (Hrincius et al. 2011). Taken together, PI $3 K$ signaling can be induced by IV via several mechanisms in the invaded host cell with dynamically and mechanistically separated modes of activation, which may result in different functions of the kinase during influenza life cycle progression.

Accordingly, PI3K signaling has been attributed to diverse functions in the course of IV propagation. During virus attachment and internalization, IV-triggered PI3K activation was described as supportive for host cell-mediated virus uptake processes (Ehrhardt et al. 2006; Eierhoff et al. 2010). More controversially discussed is the role of NS1-mediated PI3K activation. Initial studies concerning phenotypical consequences suggested a prevention of premature apoptotic responses of infected cells, supported by the finding of a PI3K/Akt-mediated blockade of pro-apoptotic factors (Ehrhardt et al. 2007a; Shin et al. 2007b; Zhirnov and Klenk 2007). This proposed function, however, is still under debate as shown in a more recent study in which disruption of NS1 motifs that are essential for NS1-driven PI3K activation did not result in increased apoptosis of infected cells (Jackson et al. 2010). Furthermore, the impact of NS1mediated PI3K activation on IV pathogenicity was analyzed in vivo, showing that it is critical for virus replication and pathogenicity but in a virus strain-dependent manner (Ayllon et al. 2012; Hrincius et al. 2012). Additional data imply a regulatory interplay of p 85 binding sites and non-p85 binding domains in NS1 for regulation of virus replication and virulence (Fan et al. 2013). Further studies on PI3K functions during the IV life cycle described an impact on viral RNA and protein synthesis as well as on nuclear export of vRNPs (Shin et al. 2007c) and even provided first indications for a potential involvement of PI3K in viral mRNA export from the nucleus (Pereira et al. 2018).

In addition to the above-described virussupportive functions, an antiviral activity of PI3K has also been suggested, supported by the finding that engagement of the RIG-I pathway also activates PI3K and is needed for full activation of the type I IFN system (Hrincius et al. 2011). This is in line with earlier descriptions of a role of PI3K in IV-induced phosphorylation of IRF3, which is needed as a costimulatory signal for full induction of the type I IFN response (Ehrhardt et al. 2006).

Since pro- and antiviral activities of the PI3 kinase have been described, the effect of ectopic blockade of PI3K signaling on IV replication was analyzed and multiple studies confirmed that the virus-supportive functions seem to outweigh the antiviral activities of the kinase (Ehrhardt et al. 2006; Shin et al. 2007c; Hirata et al. 2014).

Recently, a functional link between metabolic reprogramming of IV-infected cells and PI3K activities was established (Smallwood et al. 2017). Therefore, a role of PI3K in the regulation of host cell metabolism during IV infections can be postulated and added to the list of PI3K functions during IV life cycle progression. In addition, these data support the idea of PI3K signaling inhibition as potential antiviral intervention. Along this line, it is noteworthy that a clinical study using inhibitors of mTOR, a downstream factor of the PI3K/Akt signaling 
network, improves outcomes in patients with severe H1N1 pneumonia and acute respiratory failure (Wang et al. 2014).

In general, PI3K signaling without a doubt represents an important host cell signaling module for efficient virus growth. However, more research is needed to understand the distinct PI3K functions in IV infections in more detail. Emphasizing the general importance of PI3K signaling in the influenza life cycle, dynamic evolutionary changes in $\mathrm{p} 85$ binding sites in the NS1 protein can be detected in human viruses over time, illustrating ongoing shaping and evolutionary regulation of this important virus-host interaction (Lopes et al. 2017). The overall function of PI3K in infected cells, however, still remains elusive. Most importantly, the proposed mechanism of a NS1-mediated functional switch of the kinase from supporting the induction of the antiviral-acting type I IFN re-
Influenza Virus and Cellular Signal Transduction

sponse to a NS1-driven virus-supportive function still deserves more attention and research.

\section{CONCLUDING REMARKS}

Host-directed antiviral therapies are a promising tool to overcome treatment limitations raised by rapidly changing pathogens with high evolution rates; IV research of the past years without a doubt indicated the suitability and safety of targeting cellular signaling pathways comprising NF-kB, MAPKs, or PI3K, which was confirmed in first clinical trials using mTOR, NF- $\mathrm{kB}$, and MEK inhibitors. However, these studies also highlighted the many unanswered questions, mainly regarding the molecular modes of action, because the functions of these factors in IV infections are highly diverse and seem to depend on the respective activating signaling cascades (Fig. 4). Further research is

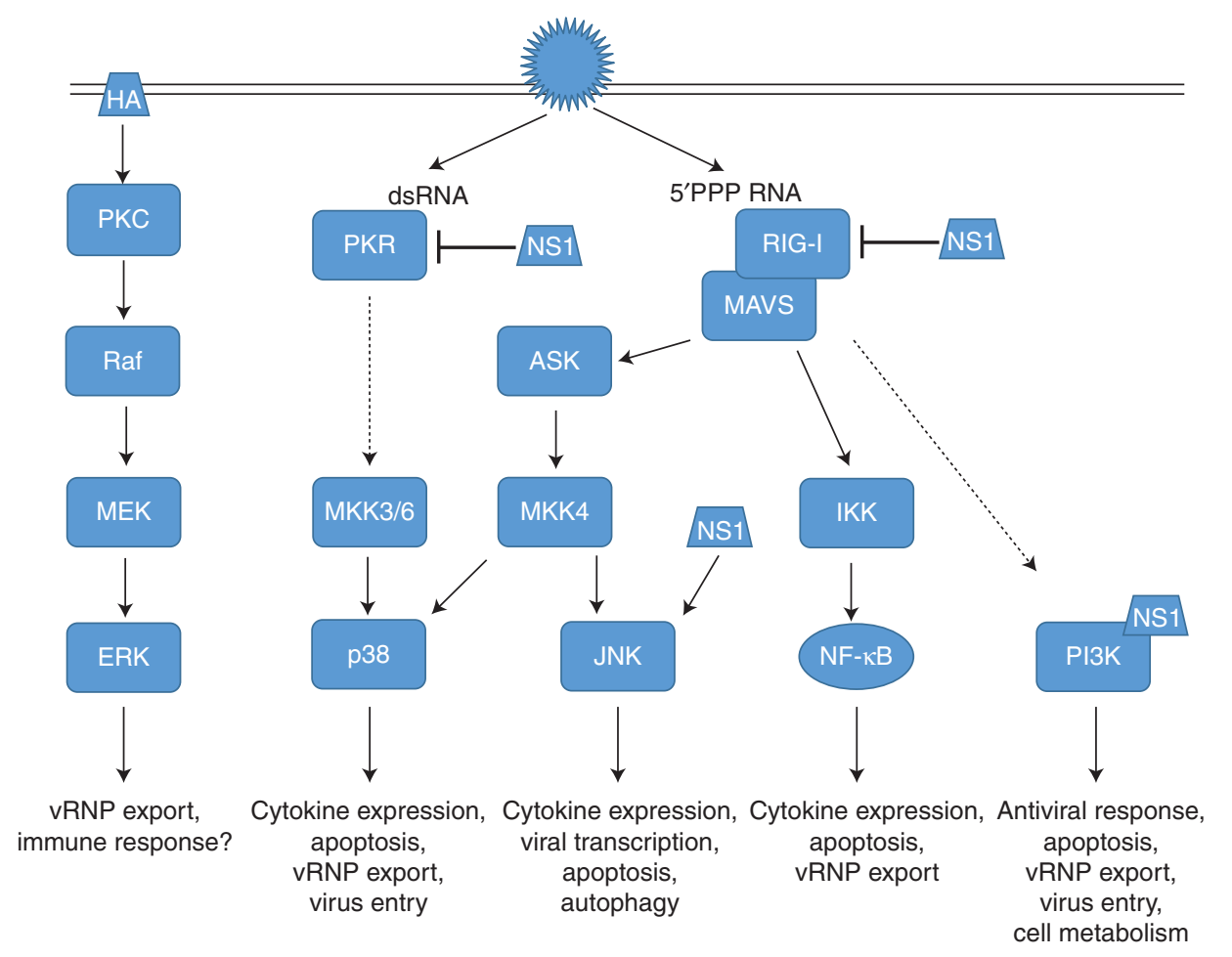

Figure 4. Schematic overview of antiviral and virus-supportive activities of cellular signal transduction pathways. Shown are signaling cascades induced by influenza virus (IV) infection, viral mediators of induction, and viral suppressors, as well as respective consequences of activation. See the text for details. 
S. Ludwig et al.

needed to improve our understanding of the detailed role specific pathways play in virus replication or immune responses to identify the most promising targets of specific signaling transduction pathways. Repurposing of clinically approved drugs with well-defined pharmacokinetics and side effects will be key to the fast and safe development of new antivirals that target host restriction factors to efficiently reduce disease severity of IV infections and improve patient outcome.

\section{ACKNOWLEDGMENTS}

The authors' work relevant for this article was supported by funding from the German Research Foundation (DFG) grants SFB1009B02, BO5122/1-1, CRU342, and CRU341).

This article has been made freely available online courtesy of TAUNS Laboratories.

\section{REFERENCES}

Amatore D, Sgarbanti R, Aquilano K, Baldelli S, Limongi D, Civitelli L, Nencioni L, Garaci E, Ciriolo MR, Palamara AT. 2015. Influenza virus replication in lung epithelial cells depends on redox-sensitive pathways activated by NOX4-derived ROS. Cell Microbiol 17: 131-145. doi:10 $.1111 / \mathrm{cmi} .12343$

Ayllon J, Hale BG, García-Sastre A. 2012. Strain-specific contribution of NS1-activated phosphoinositide 3-kinase signaling to influenza A virus replication and virulence. J Virol 86: 5366-5370. doi:10.1128/JVI.06722-11

Bogoyevitch MA, Ngoei KR, Zhao TT, Yeap YY, Ng DC. 2010. c-Jun N-terminal kinase (JNK) signaling: recent advances and challenges. Biochim Biophys Acta 1804: 463-475. doi:10.1016/j.bbapap.2009.11.002

Börgeling Y, Schmolke M, Viemann D, Nordhoff C, Roth J, Ludwig S. 2014. Inhibition of p38 mitogen-activated protein kinase impairs influenza virus-induced primary and secondary host gene responses and protects mice from lethal H5N1 infection. J Biol Chem 289: 13-27. doi:10 $.1074 /$ jbc.M113.469239

Bruchhagen C, Jarick M, Mewis C, Hertlein T, Niemann S, Ohlsen K, Peters G, Planz O, Ludwig S, Ehrhardt C. 2018. Metabolic conversion of CI-1040 turns a cellular MEKinhibitor into an antibacterial compound. Sci Rep 8: 9114. doi:10.1038/s41598-018-27445-7

Brydon EW, Morris SJ, Sweet C. 2005. Role of apoptosis and cytokines in influenza virus morbidity. FEMS Microbiol Rev 29: 837-850. doi:10.1016/j.femsre.2004.12.003.

Cargnello M, Roux PP. 2011. Activation and function of the MAPKs and their substrates, the MAPK-activated protein kinases. Microbiol Mol Biol Rev 75: 50-83. doi:10.1128/ MMBR.00031-10.
Cheng Y, Tian H. 2017. Current development status of MEK inhibitors. Molecules 22: 1551. doi: 10.3390/mole cules22101551

Choi MS, Heo J, Yi CM, Ban J, Lee NJ, Lee NR, Kim SW, Kim NJ, Inn KS. 2016. A novel p38 mitogen activated protein kinase (MAPK) specific inhibitor suppresses respiratory syncytial virus and influenza A virus replication by inhibiting virus-induced p38 MAPK activation. Biochem Biophys Res Commun 477: 311-316. doi:10.1016/j.bbrc.2016 .06 .111

Cuadrado A, Nebreda AR. 2010. Mechanisms and functions of p38 MAPK signalling. Biochem J 429: 403-417. doi:10 .1042/BJ20100323

Dam S, Kracht M, Pleschka S, Schmitz ML. 2016. The influenza A virus genotype determines the antiviral function of NF-кB. J Virol 90: 7980-7990. doi:10.1128/JVI.00946-16

Droebner K, Pleschka S, Ludwig S, Planz O. 2011. Antiviral activity of the MEK-inhibitor U0126 against pandemic H1N1v and highly pathogenic avian influenza virus in vitro and in vivo. Antiviral Res 92: 195-203. doi:10 .1016/j.antiviral.2011.08.002

Droebner K, Haasbach E, Dudek SE, Scheuch G, Nocker K, Canisius S, Ehrhardt C, von Degenfeld G, Ludwig S, Planz O. 2017. Pharmacodynamics, pharmacokinetics, and antiviral activity of BAY 81-8781, a novel NF- $\kappa$ B inhibiting anti-influenza drug. Front Microbiol 8: 2130. doi:10.3389/ fmicb.2017.02130

Dudek SE, Wixler L, Nordhoff C, Nordmann A, Anhlan D, Wixler V, Ludwig S. 2011. The influenza virus PB1-F2 protein has interferon antagonistic activity. Biol Chem 392: 1135-1144. doi:10.1515/BC.2011.174

Ehrhardt C, Ludwig S. 2009. A new player in a deadly game: influenza viruses and the PI3K/Akt signalling pathway. Cell Microbiol 11: 863-871. doi:10.1111/j.14625822.2009.01309.x

Ehrhardt C, Marjuki H, Wolff T, Nurnberg B, Planz O, Pleschka S, Ludwig S. 2006. Bivalent role of the phosphatidylinositol-3-kinase (PI3K) during influenza virus infection and host cell defence. Cell Microbiol 8: 13361348. doi:10.1111/j.1462-5822.2006.00713.x

Ehrhardt C, Wolff T, Pleschka S, Planz O, Beermann W, Bode JG, Schmolke M, Ludwig S. 2007a. Influenza A virus NS1 protein activates the PI3K/Akt pathway to mediate antiapoptotic signaling responses. J Virol 81: 3058-3067. doi:10.1128/JVI.02082-06

Ehrhardt C, Wolff T, Ludwig S. 2007b. Activation of phosphatidylinositol 3-kinase signaling by the nonstructural NS1 protein is not conserved among type A and B influenza viruses. J Virol 81: 12097-12100. doi:10.1128/JVI .01216-07

Ehrhardt C, Rückle A, Hrincius ER, Haasbach E, Anhlan D, Ahmann K, Banning C, Reiling SJ, Kühn J, Strobl S, et al. 2013. The NF- $\kappa B$ inhibitor SC75741 efficiently blocks influenza virus propagation and confers a high barrier for development of viral resistance. Cell Microbiol 15: 1198-1211. doi:10.1111/cmi.12108

Eierhoff T, Hrincius ER, Rescher U, Ludwig S, Ehrhardt C. 2010. The epidermal growth factor receptor (EGFR) promotes uptake of influenza A viruses (IAV) into host cells. PLoS Pathog 6: e1001099. doi:10.1371/journal.ppat.100 1099 
Eisfeld AJ, Neumann G, Kawaoka Y. 2015. At the centre: influenza A virus ribonucleoproteins. Nat Rev Microbiol 13: 28-41. doi:10.1038/nrmicro3367

Fan S, Macken CA, Li C, Ozawa M, Goto H, Iswahyudi NF, Nidom CA, Chen H, Neumann G, Kawaoka Y. 2013. Synergistic effect of the PDZ and p85 $\beta$-binding domains of the NS1 protein on virulence of an avian H5N1 influenza A virus. J Virol 87: 4861-4871. doi:10.1128/JVI .02608-12

García-Sastre A. 2017. Ten strategies of interferon evasion by viruses. Cell Host Microbe 22: 176-184. doi:10.1016/j .chom.2017.07.012

Graef KM, Vreede FT, Lau YF, McCall AW, Carr SM, Subbarao K, Fodor E. 2010. The PB2 subunit of the influenza virus RNA polymerase affects virulence by interacting with the mitochondrial antiviral signaling protein and inhibiting expression of beta interferon. J Virol 84: 8433-8445. doi:10.1128/JVI.00879-10

Growcott EJ, Bamba D, Galarneau JR, Leonard VHJ, Schul W, Stein D, Osborne CS. 2018. The effect of P38 MAP kinase inhibition in a mouse model of influenza. J Med Microbiol 67: 452-462. doi:10.1099/jmm.0.000684.

Haasbach E, Reiling SJ, Ehrhardt C, Droebner K, Ruckle A Hrincius ER, Leban J, Strobl S, Vitt D, Ludwig S, et al 2013a. The NF- $\kappa B$ inhibitor SC75741 protects mice against highly pathogenic avian influenza A virus. Antiviral Res 99: 336-344. doi:10.1016/j.antiviral.2013.06.008

Haasbach E, Hartmayer C, Planz O. 2013b. Combination of MEK inhibitors and oseltamivir leads to synergistic antiviral effects after influenza A virus infection in vitro. $A n-$ tiviral Res 98: 319-324. doi:10.1016/j.antiviral.2013.03 .006

Haasbach E, Müller C, Ehrhardt C, Schreiber A, Pleschka S, Ludwig S, Planz O. 2017. The MEK-inhibitor CI-1040 displays a broad anti-influenza virus activity in vitro and provides a prolonged treatment window compared to standard of care in vivo. Antiviral Res 142: 178-184. doi:10.1016/j.antiviral.2017.03.024

Hale BG, Jackson D, Chen YH, Lamb RA, Randall RE. 2006. Influenza A virus NS1 protein binds $\mathrm{p} 85 \beta$ and activates phosphatidylinositol-3-kinase signaling. Proc Natl Acad Sci 103: 14194-14199. doi:10.1073/pnas.0606109103

Hale BG, Randall RE, Ortin J, Jackson D. 2008a. The multifunctional NS1 protein of influenza A viruses. J Gen Virol 89: 2359-2376. doi:10.1099/vir.0.2008/004606-0

Hale BG, Batty IH, Downes CP, Randall RE. 2008b. Binding of influenza A virus NS1 protein to the inter-SH2 domain of $\mathrm{p} 85 \beta$ suggests a novel mechanism for phosphoinositide 3-kinase activation. J Biol Chem 283: 1372-1380. doi:10 $.1074 /$ jbc.M708862200

Hale BG, Kerry PS, Jackson D, Precious BL, Gray A, Killip MJ, Randall RE, Russell RJ. 2010. Structural insights into phosphoinositide 3-kinase activation by the influenza A virus NS1 protein. Proc Natl Acad Sci 107: 1954-1959. doi:10.1073/pnas.0910715107

Han J, Lee JD, Bibbs L, Ulevitch RJ. 1994. A MAP kinase targeted by endotoxin and hyperosmolarity in mammalian cells. Science 265: 808-811. doi:10.1126/science .791403

Hayashi S, Jibiki I, Asai Y, Gon Y, Kobayashi T, Ichiwata T, Shimizu K, Hashimoto S. 2008. Analysis of gene expression in human bronchial epithelial cells upon influenza virus infection and regulation by $\mathrm{p} 38$ mitogen-activated protein kinase and c-Jun-N-terminal kinase. Respirology 13: 203-214. doi:10.1111/j.1440-1843.2007.01204.x

Hibi M, Lin A, Smeal T, Minden A, Karin M. 1993. Identification of an oncoprotein- and UV-responsive protein kinase that binds and potentiates the c-Jun activation domain. Genes Dev 7: 2135-2148. doi:10.1101/gad.7.11 2135 .

Hirata N, Suizu F, Matsuda-Lennikov M, Edamura T, Bala J, Noguchi M. 2014. Inhibition of Akt kinase activity suppresses entry and replication of influenza virus. Biochem Biophys Res Commun 450: 891-898. doi:10.1016/j.bbrc 2014.06.077

Hornung V, Ellegast J, Kim S, Brzozka K, Jung A, Kato H, Poeck H, Akira S, Conzelmann KK, Schlee M, et al. 2006. $5^{\prime}$-Triphosphate RNA is the ligand for RIG-I. Science 314: 994-997. doi:10.1126/science.1132505.

Hrincius ER, Wixler V, Wolff T, Wagner R, Ludwig S, Ehrhardt C. 2010. CRK adaptor protein expression is required for efficient replication of avian influenza A viruses and controls JNK-mediated apoptotic responses. Cell Microbiol 12: 831-843. doi:10.1111/j.1462-5822.2010 $.01436 . \mathrm{x}$

Hrincius ER, Dierkes R, Anhlan D, Wixler V, Ludwig S, Ehrhardt C. 2011. Phosphatidylinositol-3-kinase (PI3K) is activated by influenza virus vRNA via the pathogen pattern receptor Rig-I to promote efficient type I interferon production. Cell Microbiol 13: 1907-1919. doi:10 $.1111 / \mathrm{j} .1462-5822.2011 .01680 . x$

Hrincius ER, Hennecke AK, Gensler L, Nordhoff C, Anhlan D, Vogel P, McCullers JA, Ludwig S, Ehrhardt C. 2012. A single point mutation $(\mathrm{Y} 89 \mathrm{~F})$ within the non-structural protein 1 of influenza A viruses limits epithelial cell tropism and virulence in mice. Am J Pathol 180: 2361-2374. doi:10.1016/j.ajpath.2012.02.029

Hui KP, Lee SM, Cheung CY, Ng IH, Poon LL, Guan Y, Ip NY, Lau AS, Peiris JS. 2009. Induction of proinflammatory cytokines in primary human macrophages by influenza A virus (H5N1) is selectively regulated by IFN regulatory factor 3 and p38 MAPK. J Immunol 182: 1088 1098. doi:10.4049/jimmunol.182.2.1088

Jackson D, Killip MJ, Galloway CS, Russell RJ, Randall RE. 2010. Loss of function of the influenza A virus NS1 protein promotes apoptosis but this is not due to a failure to activate phosphatidylinositol 3-kinase (PI3K). Virology 396: 94-105. doi:10.1016/j.virol.2009.10.004

Jiang M, Österlund P, Fagerlund R, Rios DN, Hoffmann A, Poranen MM, Bamford DH, Julkunen I. 2015. MAP kinase $\mathrm{p} 38 \alpha$ regulates type III interferon (IFN- $\lambda 1$ ) gene expression in human monocyte-derived dendritic cells in response to RNA stimulation. J Leukoc Biol 97: 307320. doi:10.1189/jlb.2A0114-059RR

Kakugawa S, Shimojima M, Goto H, Horimoto T, Oshimori N, Neumann G, Yamamoto T, Kawaoka Y. 2009. Mitogen-activated protein kinase-activated kinase RSK2 plays a role in innate immune responses to influenza virus infection. J Virol 83: 2510-2517. doi:10.1128/JVI.02416-08

Katso R, Okkenhaug K, Ahmadi K, White S, Timms J, Waterfield MD. 2001. Cellular function of phosphoinositide 3-kinases: implications for development, homeostasis, and cancer. Annu Rev Cell Dev Biol 17: 615-675. doi:10.1146/annurev.cellbio.17.1.615 
S. Ludwig et al.

Killip MJ, Fodor E, Randall RE. 2015. Influenza virus activation of the interferon system. Virus Res 209: 11-22. doi:10.1016/j.virusres.2015.02.003

Köther K, Nordhoff C, Masemann D, Varga G, Bream JH, Gaestel M, Wixler V, Ludwig S. 2014. MAPKAP kinase 3 suppresses Ifng gene expression and attenuates NK cell cytotoxicity and Th1 CD4 T-cell development upon influenza A virus infection. FASEB J 28: 4235-4246. doi:10 $.1096 /$ fj.14-249599

Kramer A, Liashkovich I, Oberleithner H, Ludwig S, Mazur I, Shahin V. 2008. Apoptosis leads to a degradation of vital components of active nuclear transport and a dissociation of the nuclear lamina. Proc Natl Acad Sci 105: 11236 11241. doi:10.1073/pnas.0801967105

Krischuns T, Günl F, Henschel L, Binder M, Willemsen J, Schloer S, Rescher U, Gerlt V, Zimmer G, Nordhoff C, et al. 2018. Phosphorylation of TRIM28 enhances the expression of IFN- $\beta$ and proinflammatory cytokines during HPAIV infection of human lung epithelial cells. Front Immunol 9: 2229. doi:10.3389/fimmu.2018.02229

Krug RM. 2015. Functions of the influenza A virus NS1 protein in antiviral defense. Curr Opin Virol 12: 1-6. doi:10.1016/j.coviro.2015.01.007

Kujime K, Hashimoto S, Gon Y, Shimizu K, Horie T. 2000. p38 mitogen-activated protein kinase and c-jun- $\mathrm{NH}_{2}$-terminal kinase regulate RANTES production by influenza virus-infected human bronchial epithelial cells. J Immunol 164: 3222-3228. doi:10.4049/jimmunol.164.6.3222

Kumar R, Herbert PE, Warrens AN. 2005. An introduction to death receptors in apoptosis. Int J Surg 3: 268-277. doi:10.1016/j.ijsu.2005.05.002

Kumar N, Xin ZT, Liang Y, Ly H, Liang Y. 2008. NF-кB signaling differentially regulates influenza virus RNA synthesis. J Virol 82: 9880-9889. doi:10.1128/JVI.00909-08

Kuroki T, Osari S, Nagata K, Kawaguchi A. 2018. Influenza A virus NS1 protein suppresses JNK1-dependent autophagosome formation mediated by Rab1la recycling endosomes. Front Microbiol 9: 3120. doi:10.3389/fmicb.2018 .03120

Kyriakis JM, Avruch J. 1990. pp54 microtubule-associated protein 2 kinase. A novel serine/threonine protein kinase regulated by phosphorylation and stimulated by poly-Llysine. J Biol Chem 265: 17355-17363.

Lawrence T. 2009. The nuclear factor NF-кB pathway in inflammation. Cold Spring Harb Perspect Biol 1: a001651. doi:10.1101/cshperspect.a001651

Lee JC, Laydon JT, McDonnell PC, Gallagher TF, Kumar S, Green D, McNulty D, Blumenthal MJ, Heys JR, Landvatter SW, et al. 1994. A protein kinase involved in the regulation of inflammatory cytokine biosynthesis. Nature 372: 739-746. doi:10.1038/372739a0

Li W, Wang G, Zhang H, Shen Y, Dai J, Wu L, Zhou J, Jiang Z, Li K. 2012. Inability of NS1 protein from an H5N1 influenza virus to activate PI3K/Akt signaling pathway correlates to the enhanced virus replication upon PI3K inhibition. Vet Res 43: 36. doi:10.1186/1297-9716-43-36

Liedmann S, Hrincius ER, Guy C, Anhlan D, Dierkes R, Carter R, Wu G, Staeheli P, Green DR, Wolff T, et al. 2014. Viral suppressors of the RIG-I-mediated interferon response are pre-packaged in influenza virions. Nat Commun 5: 5645. doi:10.1038/ncomms6645
Lin C, Zimmer SG, Lu Z, Holland RE Jr, Dong Q, Chambers TM. 2001. The involvement of a stress-activated pathway in equine influenza virus-mediated apoptosis. Virology 287: 202-213. doi:10.1006/viro.2001.1010

Lopes AM, Domingues P, Zell R, Hale BG. 2017. Structureguided functional annotation of the influenza A virus NS1 protein reveals dynamic evolution of the p85 $\beta$-binding site during circulation in humans. J Virol 91: e0108117. doi:10.1128/JVI.01081-17

Lopez-Castejon G, Brough D. 2011. Understanding the mechanism of IL-1 $\beta$ secretion. Cytokine Growth Factor Rev 22: 189-195. doi:10.1016/j.cytogfr.2011.10.001

Ludwig S. 2009. Targeting cell signalling pathways to fight the flu: towards a paradigm change in anti-influenza therapy. J Antimicrob Chemother 64: 1-4. doi:10.1093/jac/ dkp161

Ludwig S, Ehrhardt C, Neumeier ER, Kracht M, Rapp UR, Pleschka S. 2001. Influenza virus-induced AP-1-dependent gene expression requires activation of the JNK signaling pathway. J Biol Chem 276: 10990-10998. doi:10 $.1074 / j b c . M 009902200$

Ludwig S, Wang X, Ehrhardt C, Zheng H, Donelan N, Planz O, Pleschka S, García-Sastre A, Heins G, Wolff T. 2002. The influenza A virus NS1 protein inhibits activation of Jun N-terminal kinase and AP-1 transcription factors. J Virol 76: 11166-11171. doi:10.1128/JVI.76.21.1116611171.2002

Ludwig S, Wolff T, Ehrhardt C, Wurzer WJ, Reinhardt J, Planz O, Pleschka S. 2004. MEK inhibition impairs influenza $B$ virus propagation without emergence of resistant variants. FEBS Lett 561: 37-43. doi:10.1016/S0014-5793 (04)00108-5

Luig C, Köther K, Dudek SE, Gaestel M, Hiscott J, Wixler V, Ludwig S. 2010. MAP kinase-activated protein kinases 2 and 3 are required for influenza $A$ virus propagation and act via inhibition of PKR. FASEB J 24: 4068-4077. doi:10 $.1096 /$ fj.10-158766

Macé G, Miaczynska M, Zerial M, Nebreda AR. 2005. Phosphorylation of EEA1 by p38 MAP kinase regulates $\mu$ opioid receptor endocytosis. EMBO J 24: 3235-3246. doi:10 .1038/sj.emboj.7600799

Marchant D, Singhera GK, Utokaparch S, Hackett TL, Boyd JH, Luo Z, Si X, Dorscheid DR, McManus BM, Hegele RG. 2010. Toll-like receptor 4-mediated activation of p38 mitogen-activated protein kinase is a determinant of respiratory virus entry and tropism. J Virol 84: 1135911373. doi:10.1128/JVI.00804-10

Marjuki H, Alam MI, Ehrhardt C, Wagner R, Planz O, Klenk HD, Ludwig S, Pleschka S. 2006. Membrane accumulation of influenza A virus hemagglutinin triggers nuclear export of the viral genome via protein kinase $\mathrm{C} \alpha$-mediated activation of ERK signaling. J Biol Chem 281: $16707-$ 16715. doi:10.1074/jbc.M510233200

Marjuki H, Gornitzky A, Marathe BM, Ilyushina NA, Aldridge JR, Desai G, Webby RJ, Webster RG. 2011. Influenza A virus-induced early activation of ERK and PI3K mediates V-ATPase-dependent intracellular $\mathrm{pH}$ change required for fusion. Cell Microbiol 13: 587-601. doi:10 $.1111 / \mathrm{j} .1462-5822.2010 .01556 . \mathrm{x}$

Mazur I, Wurzer WJ, Ehrhardt C, Pleschka S, Puthavathana P, Silberzahn T, Wolff T, Planz O, Ludwig S. 2007. Acetylsalicylic acid (ASA) blocks influenza virus propagation 


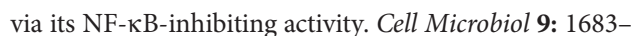
1694. doi:10.1111/j.1462-5822.2007.00902.x

McCaskill JL, Ressel S, Alber A, Redford J, Power UF, Schwarze J, Dutia BM, Buck AH. 2017. Broad-spectrum inhibition of respiratory virus infection by microRNA mimics targeting p38 MAPK signaling. Mol Ther Nucleic Acids 7: 256-266. doi:10.1016/j.omtn.2017.03.008

Morrison DK. 2012. MAP kinase pathways. Cold Spring Harb Perspect Biol 4: a011254. doi:10.1101/cshperspect .a011254

Mühlbauer D, Dzieciolowski J, Hardt M, Hocke A, Schierhorn KL, Mostafa A, Muller C, Wisskirchen C, Herold S, Wolff T, et al. 2015. Influenza virus-induced caspase-dependent enlargement of nuclear pores promotes nuclear export of viral ribonucleoprotein complexes. J Virol 89: 6009-6021. doi:10.1128/JVI.03531-14

Nacken W, Ehrhardt C, Ludwig S. 2012. Small molecule inhibitors of the c-Jun N-terminal kinase (JNK) possess antiviral activity against highly pathogenic avian and human pandemic influenza A viruses. Biol Chem 393: 525534. doi:10.1515/hsz-2011-0270

Nacken W, Anhlan D, Hrincius ER, Mostafa A, Wolff T, Sadewasser A, Pleschka S, Ehrhardt C, Ludwig S. 2014. Activation of c-jun $\mathrm{N}$-terminal kinase upon influenza A virus (IAV) infection is independent of pathogen-related receptors but dependent on amino acid sequence variations of IAV NS1. J Virol 88: 8843-8852. doi:10.1128/JVI .00424-14

Nacken W, Wixler V, Ehrhardt C, Ludwig S. 2017. Influenza A virus NS1 protein-induced JNK activation and apoptosis are not functionally linked. Cell Microbiol 19: e12721. doi:10.1111/cmi.12721

Napetschnig J, Wu H. 2013. Molecular basis of NF-кB signaling. Annu Rev Biophys 42: 443-468. doi:10.1146/an nurev-biophys-083012-130338

Nencioni L, De Chiara G, Sgarbanti R, Amatore D, Aquilano K, Marcocci ME, Serafino A, Torcia M, Cozzolino F, Ciriolo MR, et al. 2009. Bcl-2 expression and p38MAPK activity in cells infected with influenza A virus: impact on virally induced apoptosis and viral replication. J Biol Chem 284: 16004-16015. doi:10.1074/jbc.M900146200

Nimmerjahn F, Dudziak D, Dirmeier U, Hobom G, Riedel A, Schlee M, Staudt LM, Rosenwald A, Behrends U, Bornkamm GW, et al. 2004. Active NF- $\kappa B$ signalling is a prerequisite for influenza virus infection. J Gen Virol 85: 2347-2356. doi:10.1099/vir.0.79958-0

Nishimoto S, Nishida E. 2006. MAPK signalling: ERK5 versus ERK1/2. EMBO Rep 7: 782-786. doi:10.1038/sj.embor .7400755

Pahl HL. 1999. Activators and target genes of Rel/NF- $\mathrm{\kappa B}$ transcription factors. Oncogene 18: 6853-6866. doi:10 $.1038 /$ sj.onc. 1203239

Pan H, Zhang Y, Luo Z, Li P, Liu L, Wang C, Wang H, Li H, Ma Y. 2014. Autophagy mediates avian influenza H5N1 pseudotyped particle-induced lung inflammation through NF- $\kappa B$ and p38 MAPK signaling pathways. Am J Physiol Lung Cell Mol Physiol 306: L183-L195. doi:10 .1152/ajplung.00147.2013

Pauli EK, Schmolke M, Wolff T, Viemann D, Roth J, Bode JG, Ludwig S. 2008. Influenza A virus inhibits type I IFN signaling via NF- $\mathrm{kB}$-dependent induction of SOCS-3 ex- pression. PLoS Pathog 4: e1000196. doi:10.1371/journal .ppat.1000196

Pearson G, Robinson F, Beers Gibson T, Xu BE, Karandikar M, Berman K, Cobb MH. 2001. Mitogen-activated protein (MAP) kinase pathways: regulation and physiological functions. Endocr Rev 22: 153-183.

Pereira CF, Wise HM, Kurian D, Pinto RM, Amorim MJ, Gill AC, Digard P. 2018. Effects of mutations in the effector domain of influenza A virus NS1 protein. BMC Res Notes 11: 673. doi:10.1186/s13104-018-3779-6

Perot BP, Boussier J, Yatim N, Rossman JS, Ingersoll MA, Albert ML. 2018. Autophagy diminishes the early interferon- $\beta$ response to influenza A virus resulting in differential expression of interferon-stimulated genes. Cell Death Dis 9: 539. doi:10.1038/s41419-018-0546-5

Pichlmair A, Schulz O, Tan CP, Naslund TI, Liljestrom P, Weber F, Reis e Sousa C. 2006. RIG-I-mediated antiviral responses to single-stranded RNA bearing 5 ' -phosphates. Science 314: 997-1001. doi:10.1126/science.1132998

Pinto R, Herold S, Cakarova L, Hoegner K, Lohmeyer J, Planz O, Pleschka S. 2011. Inhibition of influenza virusinduced NF- $\kappa B$ and Raf/MEK/ERK activation can reduce both virus titers and cytokine expression simultaneously in vitro and in vivo. Antiviral Res 92: 45-56. doi:10.1016/j .antiviral.2011.05.009.

Planz O. 2013. Development of cellular signaling pathway inhibitors as new antivirals against influenza. Antiviral Res 98: 457-468. doi:10.1016/j.antiviral.2013.04.008

Planz O, Pleschka S, Ludwig S. 2001. MEK-specific inhibitor U0126 blocks spread of Borna disease virus in cultured cells. J Virol 75: 4871-4877. doi:10.1128/JVI.75.10.48714877.2001

Pleschka S. 2008. RNA viruses and the mitogenic Raf/MEK/ ERK signal transduction cascade. Biol Chem 389: 12731282. doi:10.1515/BC.2008.145

Pleschka S, Wolff T, Ehrhardt C, Hobom G, Planz O, Rapp UR, Ludwig S. 2001. Influenza virus propagation is impaired by inhibition of the Raf/MEK/ERK signalling cascade. Nat Cell Biol 3: 301-305. doi:10.1038/35060098

Preugschas HF, Hrincius ER, Mewis C, Tran GVQ, Ludwig S, Ehrhardt C. 2019. Late activation of the Raf/MEK/ERK pathway is required for translocation of the respiratory syncytial virus $\mathrm{F}$ protein to the plasma membrane and efficient viral replication. Cell Microbiol 21: e12955. doi:10.1111/cmi.12955

Rouse J, Cohen P, Trigon S, Morange M, Alonso-Llamazares A, Zamanillo D, Hunt T, Nebreda AR. 1994. A novel kinase cascade triggered by stress and heat shock that stimulates MAPKAP kinase-2 and phosphorylation of the small heat shock proteins. Cell 78: 1027-1037. doi:10.1016/0092-8674(94)90277-1

Santoro MG, Rossi A, Amici C. 2003. NF- $\mathrm{kB}$ and virus infection: who controls whom. $E M B O J$ 22: 2552-2560. doi:10.1093/emboj/cdg267

Scheuch G, Canisius S, Nocker K, Hofmann T, Naumann R, Pleschka S, Ludwig S, Welte T, Planz O. 2018. Targeting intracellular signaling as an antiviral strategy: aerosolized LASAG for the treatment of influenza in hospitalized patients. Emerg Microbes Infect 7: 21. doi:10.1038/ s41426-018-0023-3

Schmolke M, Viemann D, Roth J, Ludwig S. 2009. Essential impact of NF- $\kappa B$ signaling on the H5N1 influenza A 
S. Ludwig et al.

virus-induced transcriptome. J Immunol 183: 5180-5189. doi:10.4049/jimmunol.0804198

Schräder T, Dudek SE, Schreiber A, Ehrhardt C, Planz O, Ludwig S. 2018. The clinically approved MEK inhibitor trametinib efficiently blocks influenza A virus propagation and cytokine expression. Antiviral Res 157: 80-92. doi:10.1016/j.antiviral.2018.07.006

Shin YK, Liu Q, Tikoo SK, Babiuk LA, Zhou Y. 2007a. Influenza A virus NS1 protein activates the phosphatidylinositol 3-kinase (PI3K)/Akt pathway by direct interaction with the p85 subunit of PI3K. J Gen Virol 88: 13-18. doi:10.1099/vir.0.82419-0

Shin YK, Li Y, Liu Q, Anderson DH, Babiuk LA, Zhou Y. 2007b. SH3 binding motif 1 in influenza A virus NS1 protein is essential for PI3K/Akt signaling pathway activation. J Virol 81: 12730-12739. doi:10.1128/JVI .01427-07

Shin YK, Liu Q, Tikoo SK, Babiuk LA, Zhou Y. 2007c. Effect of the phosphatidylinositol 3-kinase/Akt pathway on influenza A virus propagation. J Gen Virol 88: 942-950. doi:10.1099/vir.0.82483-0

Smallwood HS, Duan S, Morfouace M, Rezinciuc S, Shulkin BL, Shelat A, Zink EE, Milasta S, Bajracharya R, Oluwaseum AJ, et al. 2017. Targeting metabolic reprogramming by influenza infection for therapeutic intervention. Cell Rep 19: 1640-1653. doi:10.1016/j.celrep.2017.04.039

Stanifer ML, Pervolaraki K, Boulant S. 2019. Differential regulation of type I and type III interferon signaling. Int J Mol Sci 20: 1445. doi:10.3390/ijms20061445

Takeuchi O, Akira S. 2008. MDA5/RIG-I and virus recognition. Curr Opin Immunol 20: 17-22. doi:10.1016/j.coi .2008 .01 .002

Thorpe LM, Yuzugullu H, Zhao JJ. 2015. PI3K in cancer: divergent roles of isoforms, modes of activation and therapeutic targeting. Nat Rev Cancer 15: 7-24. doi:10.1038/ nrc3860

Turkington HL, Juozapaitis M, Tsolakos N, Corrales-Aguilar E, Schwemmle M, Hale BG. 2018. Unexpected functional divergence of bat influenza virus NS1 proteins. J Virol 92: e02097-17. doi: 10.1128/JVI.02097-17

Vanhaesebroeck B, Leevers SJ, Panayotou G, Waterfield MD. 1997. Phosphoinositide 3-kinases: a conserved family of signal transducers. Trends Biochem Sci 22: 267-272. doi:10.1016/S0968-0004(97)01061-X

Vanhaesebroeck B, Whitehead MA, Piñeiro R. 2016. Molecules in medicine mini-review: isoforms of PI3K in biology and disease. J Mol Med (Berl) 94: 5-11. doi:10.1007/ s00109-015-1352-5

Varga ZT, Ramos I, Hai R, Schmolke M, García-Sastre A, Fernandez-Sesma A, Palese P. 2011. The influenza virus protein PB1-F2 inhibits the induction of type I interferon at the level of the MAVS adaptor protein. PLoS Pathog 7: e1002067. doi:10.1371/journal.ppat.1002067

Viemann D, Schmolke M, Lueken A, Boergeling Y, Friesenhagen J, Wittkowski H, Ludwig S, Roth J. 2011. H5N1 virus activates signaling pathways in human endothelial cells resulting in a specific imbalanced inflammatory re- sponse. J Immunol 186: 164-173. doi:10.4049/jimmunol .0904170

Wang CH, Chung FT, Lin SM, Huang SY, Chou CL, Lee KY, Lin TY, Kuo HP. 2014. Adjuvant treatment with a mammalian target of rapamycin inhibitor, sirolimus, and steroids improves outcomes in patients with severe $\mathrm{H} 1 \mathrm{~N} 1$ pneumonia and acute respiratory failure. Crit Care Med 42: 313-321. doi:10.1097/CCM.0b013e3182a2727d

Wang C, Liu H, Luo J, Chen L, Li M, Su W, Zhao N, Liu S, Xie L, Jia Y, et al. 2017. HA triggers the switch from MEK1 SUMOylation to phosphorylation of the ERK pathway in influenza A virus-infected cells and facilitates its infection. Front Cell Infect Microbiol 7: 27.

Weber-Gerlach M, Weber F. 2016. To conquer the host, influenza virus is packing it in: interferon-antagonistic strategies beyond NS1. J Virol 90: 8389-8394. doi:10 .1128/JVI.00041-16

Wei L, Sandbulte MR, Thomas PG, Webby RJ, Homayouni R, Pfeffer LM. 2006. NFkB negatively regulates interferon-induced gene expression and anti-influenza activity. J Biol Chem 281: 11678-11684. doi:10.1074/jbc.M51 3286200

Wei D, Huang ZH, Zhang RH, Wang CL, Xu MJ, Liu BJ, Wang GH, Xu T. 2014. Roles of p38 MAPK in the regulation of the inflammatory response to swine influenza virus-induced acute lung injury in mice. Acta Virol 58: 374-379. doi:10.4149/av_2014_04_374

Wurzer WJ, Planz O, Ehrhardt C, Giner M, Silberzahn T, Pleschka S, Ludwig S. 2003. Caspase 3 activation is essential for efficient influenza virus propagation. $E M B O J$ 22: 2717-2728. doi:10.1093/emboj/cdg279

Wurzer WJ, Ehrhardt C, Pleschka S, Berberich-Siebelt F, Wolff T, Walczak H, Planz O, Ludwig S. 2004. NF-кBdependent induction of tumor necrosis factor-related apoptosis-inducing ligand (TRAIL) and Fas/FasL is crucial for efficient influenza virus propagation. J Biol Chem 279: 30931-30937. doi:10.1074/jbc.M403258200

Yewdell J, García-Sastre A. 2002. Influenza virus still surprises. Curr Opin Microbiol 5: 414-418. doi:10.1016/S13695274(02)00346-6

Zhang S, Tian H, Cui J, Xiao J, Wang M, Hu Y. 2016. The cJun N-terminal kinase (JNK) is involved in H5N1 influenza A virus RNA and protein synthesis. Arch Virol 161: 345-351. doi:10.1007/s00705-015-2668-8

Zhang J, Ruan T, Sheng T, Wang J, Sun J, Wang J, Prinz RA, Peng D, Liu X, Xu X. 2019. Role of c-Jun terminal kinase (JNK) activation in influenza A virus-induced autophagy and replication. Virology 526: 1-12. doi:10.1016/j.virol .2018.09.020

Zhao Y, Adjei AA. 2014. The clinical development of MEK inhibitors. Nat Rev Clin Oncol 11: 385-400. doi:10.1038/ nrclinonc.2014.83

Zhirnov OP, Klenk HD. 2007. Control of apoptosis in influenza virus-infected cells by up-regulation of Akt and p53 signaling. Apoptosis 12: 1419-1432. doi:10.1007/s10495007-0071-y 


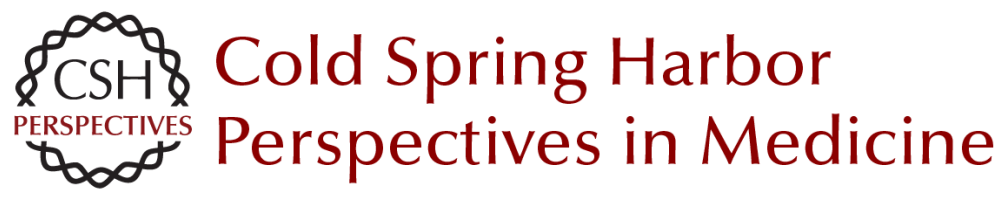

\title{
The Two Sides of the Same Coin--Influenza Virus and Intracellular Signal Transduction
}

\author{
Stephan Ludwig, Eike R. Hrincius and Yvonne Boergeling
}

Cold Spring Harb Perspect Med 2021; doi: 10.1101/cshperspect.a038513 originally published online December 23, 2019

\section{Subject Collection Influenza: The Cutting Edge}

\section{Emerging HxNy Influenza A Viruses William J. Liu, Yan Wu, Yuhai Bi, et al. \\ Equine Influenza Thomas M. Chambers \\ Human Influenza Epidemiology
Sukhyun Ryu and Benjamin J. Cowling}

Host Cell Factors That Interact with Influenza Virus Ribonucleoproteins Ecco Staller and Wendy S. Barclay

Induction and Evasion of Type-I Interferon Responses during Influenza A Virus Infection Raquel Muñoz-Moreno, Carles Martínez-Romero and Adolfo García-Sastre

Structure and Function of Influenza Polymerase Joanna M. Wandzik, Tomas Kouba and Stephen Cusack

H7N9 Influenza Virus in China Chengjun Li and Hualan Chen

H5 Influenza Viruses in Egypt Rabeh El-Shesheny, Ahmed Kandeil, Ahmed Mostafa, et al.

\begin{abstract}
Antivirals Targeting the Neuraminidase Larisa Gubareva and Teena Mohan

Accessory Gene Products of Influenza A Virus Rute M. Pinto, Samantha Lycett, Eleanor Gaunt, et al.

Influenza Immunization in the Context of

Preexisting Immunity Susanne L. Linderman, Ali H. Ellebedy, Carl Davis, et al.

Hemagglutinin Structure and Activities Steven J. Gamblin, Sébastien G. Vachieri, Xiaoli Xiong, et al.
\end{abstract}

Live Attenuated Cold-Adapted Influenza Vaccines Kanta Subbarao

Next-Generation Influenza Vaccines Masaru Kanekiyo and Barney S. Graham

\section{Selective Genome Packaging Mechanisms of Influenza A Viruses Takeshi Noda}

Systems Biological Analysis of Immune Response to Influenza Vaccination

Mario Cortese, Amy C. Sherman, Nadine G. Rouphael, et al.

For additional articles in this collection, see http://perspectivesinmedicine.cshlp.org/cgi/collection/ 